\title{
Low Persistence of Antipsychotic Therapy in Parkinson Disease - Intolerance, Ineffectiveness, or Inertia?
}

\section{University of Pennsylvania \\ Danielle S. Abraham \\ University of Pennsylvania \\ Dylan Thibault \\ University of Pennsylvania \\ Daniel Weintraub \\ University of Pennsylvania \\ Allison W. Willis \\ University of Pennsylvania}

Thanh Phuong Pham Nguyen ( $\sim$ phuongpn@pennmedicine.upenn.edu )

\section{Research Article}

Keywords: Parkinson disease, Parkinson disease psychosis, antipsychotics, dopamine-receptor blockers, pimavanserin, medication persistence, pharmacoepidemiology

Posted Date: April 9th, 2021

DOI: https://doi.org/10.21203/rs.3.rs-391767/v1

License: (c) (i) This work is licensed under a Creative Commons Attribution 4.0 International License. Read Full License 


\section{Abstract}

Background: Antipsychotics are used in Parkinson disease (PD) to treat psychosis, mood, and behavioral disturbances. Commonly used antipsychotics differ substantially in their potential to worsen motor symptoms through dopaminergic receptor blockade. Recent real-world data on the use and persistence of antipsychotic therapy in PD are lacking. The objectives of this study are to (1) examine the persistence to overall and initial antipsychotic therapy in individuals with PD and (2) determine whether persistence varies by drug dopamine receptor blocking activity.

Methods: We conducted a retrospective cohort study using U.S. commercially insured individuals in Optum 2001-2019. Adults age 40 years or older with PD initiating antipsychotic therapy, with continuous insurance coverage for at least six months following drug initiation, were included. Exposure to pimavanserin, quetiapine, clozapine, aripiprazole, risperidone, or olanzapine was identified based on pharmacy claims. Six-month persistence to overall and initial antipsychotic therapy was estimated by time to complete discontinuation or switching to a different antipsychotic. Cox proportional hazards models evaluated factors associated with discontinuation.

Results: Overall, $38.6 \%$ of 3,566 PD patients in our sample discontinued antipsychotic therapy after the first prescription, $61.4 \%$ continued with overal/ treatment within six months of initiation. Clozapine use was too rare to include in statistical analyses. Overall therapy discontinuation was more likely for medications with dopamine-receptor blocking activity (adjusted hazard ratios 1.76 [95\% confidence interval 1.40-2.20] for quetiapine, 2.15 [1.61-2.86] for aripiprazole, 2.12 [1.66-2.72] for risperidone, and 2.07 1.60-2.67] for olanzapine), compared with serotonin receptor-specific pimavanserin. Initial antipsychotic therapy discontinuation also associated greater dopamine-receptor blocking activity medication use - adjusted hazard ratios 1.57 (95\% confidence interval 1.28-1.94), 1.88 (1.43-2.46), 2.00 (1.59-2.52) and 2.03 (1.60-2.58) for quetiapine, aripiprazole, risperidone, and olanzapine, respectively, compared with pimavanserin. Similar results were observed in sensitivity analyses.

Conclusions: Over one-third of individuals with PD stop antipsychotic therapy, especially if the initial drug has greater dopamine-receptor blocking activity. Understanding the drivers of antipsychotic discontinuation, including ineffectiveness, potentially inappropriate use, clinician inertia, patient adherence and adverse effects, is needed to inform clinical management of psychosis in PD and appropriate antipsychotic use in this population.

\section{Background}

Psychosis occurs in up to $60 \%$ of persons with Parkinson disease (PD), typically in later disease stages.[1-3] PD progression and treatment with dopaminergic medications are posited to drive PD psychosis (PDP) development; therefore, clinical guidelines recommend that outpatient PDP management begins with reducing or discontinuing anti-parkinsonian medications, if possible.[4] When additional measures are needed, antipsychotic (AP) therapy is recommended. [4, 5] Pimavanserin recently became the first AP approved by the United States (U.S.) Food and Drug Administration specifically and solely for the PDP treatment.[4, 5] However, second-generation or atypical AP - clozapine, quetiapine, risperidone, olanzapine, and aripiprazole have long been prescribed off-label for PDP,[4-7] as well as for behavioral or mood disturbance in adults with neurodegenerative disease,[8-10] although use for the latter indications and in older adult populations is discouraged by clinical safety guidelines. $[5,11,12]$

Safety and tolerance data for AP use in PD patients has traditionally focused on dopamine receptor antagonism leading to worsening of parkinsonism. Most APs have some dopamine type 2 (D2) receptor antagonism and can cause drug-induced parkinsonism and tardive dyskinesia, although this risk is less in atypical APs than in typical APs (e.g. haloperidol).[13-15] In contrast, pimavanserin is a selective serotonin type 2A (5-HT2A) inverse agonist, with negligible binding at almost all other receptors targeted by atypical APs, and thus is expected to treat psychosis symptoms in PD without worsening motor symptoms.[14, 16]

Data on the use and persistence of AP therapy in the PD population, which would be essential to understand clinical decision making and safety, is limited.[17-19] AP discontinuation or switching (i.e., non-persistence to AP therapy) could be due to 
adverse effects, resolution of a provoked psychosis, or failure to respond to AP therapy.[20,21] The objective of the current study is to determine (1) persistence to overall AP therapy (i.e., the continuation of AP therapy regardless of initial medication prescribed) and (2) persistence to initial AP therapy (i.e., the continuation of initial AP medication prescribed) and (3) the patient, clinical and medication factors associated with AP discontinuation among PD patients. Increasing our understanding of which PD patients potentially have treatment-resistant or transient psychosis will inform end-of-life care, clinical decisionmaking, and doctor-patient discussions.

\section{Methods}

\section{Overview}

We conducted a retrospective cohort study examining persistence to AP therapy in individuals with PDP, focusing on the most commonly prescribed atypical APs,[3] using a large U.S. commercial health insurance database. The Office of Regulatory Affairs of the University of Pennsylvania (Philadelphia, PA) granted Institutional Review Board exemption for this study. All methods were performed in accordance with the relevant guidelines and regulations.

\section{Data source}

For this study, we used the 2001-2019 Optum ${ }^{\text {TM }}$ Clinformatics ${ }^{\text {TM }}$ Data Mart (Eden Prairie, Minnesota).[22] Optum contains health care claims data from over 60 million commercially-insured persons across the U.S.[22] Available data include sociodemographic information (e.g., age, sex, race, income level, education level, etc.), medical encounters (e.g., inpatient or emergency department [ED] visits), and pharmacy prescription claims and laboratory results, among others.[22] Optum represents the commercially-insured U.S. population,[23] allowing for a large-scale and diverse study of long-term medication use.

\section{Study population}

\section{Inclusion and exclusion criteria}

We identified new users of pimavanserin, quetiapine, risperidone, aripiprazole, clozapine, or olanzapine from January 1, 2001, until June 30, 2019, using National Drug Codes from Multum Medisource Lexicon (Denver, Colorado). New users were defined as individuals without any prescription fills for any AP in the six-month baseline period before initiating one of the APs of interest.[24, 25] Individuals with loss of insurance coverage within six months of the first AP prescription were excluded. The first qualifying AP prescription was required to have a supply of at least seven days, to minimize the potential for capturing planned short-term therapy.

Within this AP new user cohort, PD patients were identified as individuals (1) having at least two separate diagnosis claims for PD documented by International Classification of Diseases, 9th and 10th Revisions, Clinical Modification (ICD-9-CM and ICD10-CM) diagnosis codes (i.e., 332, 332.0, and G20),[26, 27] and (2) with PD diagnosis preceding AP therapy. We restricted our sample to individuals aged 40-90 years. We excluded individuals with concurrent diagnosis codes for atypical parkinsonian syndromes (multiple systems atrophy, progressive supranuclear palsy, corticobasal degeneration), amyotrophic lateral sclerosis, dementia with Lewy bodies, schizophrenia, and bipolar disorder (eTable 1) or, claims for long-term facility care within six months of starting AP therapy, because these groups would be expected to have differing clinical indications for and response to AP therapy.

\section{Baseline covariates}

Sociodemographic data, including age, sex, race/ethnicity (categorized as White, Black, Asian, Hispanic, unknown, or missing), and region of residence (i.e., Northeast, Midwest, South, West, or other) were captured at the time of the first AP prescription fill. Other covariates, measured using all data recorded in the six months before AP initiation included the combined CharlsonElixhauser comorbidity score,[28, 29] the claims-based frailty index (CFI)[30], and average numbers of (1) distinct medications filled per month, (2) outpatient visits with a neurologist, (3) ED visits, and (4) inpatient admissions. 


\section{Antipsychotic persistence}

Overall persistence is defined as the continuation of AP therapy after the first AP prescription fill, regardless of the initial AP prescribed (i.e., patients are still considered persistent if there is switching to another AP). To examine overall persistence to AP therapy, we identified all AP prescription fills occurring up to six months after AP initiation using pharmacy claims dates in Optum. Time to discontinuation of AP treatment was calculated from the initial AP prescription claim date until the end date for the last AP prescription, allowing a standard 14-day grace period (i.e., prescription fill gap) between AP prescription fills.[24, 31-33] Individuals with no additional AP medication fill after the end of this grace period were categorized as discontinuing AP therapy.

We defined persistence to initial therapy as a continuation of the same AP medication initially prescribed. Similar principles were applied to examine persistence to initial AP therapy. Time to switch to new AP drug was calculated from the pharmacy claim date of the initial prescription through the expected end date of the last prescription fill of that same agent (plus the standard allowed 14-day grace period). We only captured the first prescription fill for a different AP; examining multiple switches was beyond the scope of this study and not in alignment with our study objectives.

\section{Categorizing antipsychotics by dopamine receptor antagonism}

We categorized the atypical APs based on published estimates of D2 receptor occupancy for a given AP dose.[15] Per the literature, among atypical APs used in PDP, quetiapine has the lowest affinity for the D2 receptor, followed by clozapine, aripiprazole, risperidone, with the highest D2 receptor antagonism measured in olanzapine.[15] We used pimavanserin users as the reference group as this drug is thought to have no measurable dopaminergic receptor antagonism. $[14,16]$

\section{Statistical analyses}

SAS v9.4 (Cary, North Carolina) was used to build the analytic dataset and analyze the study cohort. We defined an alpha level of 0.05 for all statistical tests. Baseline characteristics were compared between new initiators of pimavanserin, quetiapine, aripiprazole, risperidone, and olanzapine, using Chi-square or Kruskal-Wallis tests for categorical and continuous variables, respectively. We constructed Cox proportional hazards models to examine the association of patient, clinical and drug factors on the risk of discontinuation of overall and initial AP therapy. Kaplan-Meier curves were used to illustrate persistence (i.e., freedom from discontinuation) to overall and initial AP therapy. To test the robustness of our initial findings, we performed several sets of sensitivity analyses in which we (1) extended the follow-up period to 12 months after AP initiation and (2) extended the grace period for prescription refills from 14 to 30 days, and (3) excluded all individuals with any ED or hospitalization within six months prior to initiation of AP therapy.

\section{Results}

\section{Individual baseline characteristics}

We identified 3,566 individuals meeting our inclusion criteria:153 new users of pimavanserin, 2,452 of quetiapine, 169 of aripiprazole, 462 of risperidone, and 304 of olanzapine. Clozapine use was extremely rare (only 26 users satisfying our inclusion and exclusion criteria) and thus was excluded from further statistical analyses. Table 1 displays demographic, clinical, and health care use characteristics of the final study sample. Individuals initiating aripiprazole were the youngest with a median age of 72 years (interquartile range [IQR] 64-78), whereas risperidone users were the oldest at 78 years (IQR 72-83) at initiation $(p<0.0001)$. Male users were the majority for all AP medications except aripiprazole $(68.0 \%$ female $)$ and risperidone (51.3\% female). The majority of PD patients using APs were white (range: $60.0 \%$ [risperidone] $-65.7 \%$ [aripiprazole]), and the distributions of race category and geographical region were similar across individual AP drugs $(p=$ 0.268 , and $p=0.194$, respectively). 
Table 1

Characteristics of individuals with Parkinson disease initiated on antipsychotic therapy, Optum 2001-2019

\begin{tabular}{|c|c|c|c|c|c|c|c|}
\hline \multicolumn{2}{|c|}{ Characteristic Type } & \multirow{2}{*}{$\begin{array}{l}\text { Pimavanserin } \\
(n=153) \\
75(69-80)\end{array}$} & \multirow{2}{*}{$\begin{array}{l}\text { Quetiapine } \\
(n=2,452) \\
77(69- \\
82)\end{array}$} & \multirow{2}{*}{$\begin{array}{l}\text { Aripiprazole } \\
(n=169) \\
72(64-78)\end{array}$} & \multirow{2}{*}{$\begin{array}{l}\text { Risperidone } \\
(n=462) \\
78(72-83)\end{array}$} & \multirow{2}{*}{$\begin{array}{l}\text { Olanzapine } \\
(\mathbf{n = 3 0 4 )} \\
76(70-82)\end{array}$} & \multirow{2}{*}{$\begin{array}{l}p \text {-value } \\
< \\
0.0001^{\ddagger}\end{array}$} \\
\hline Demographic & $\begin{array}{l}\text { Age at initiation, } \\
\text { years median } \\
\text { (IQR) }\end{array}$ & & & & & & \\
\hline & $\begin{array}{l}\text { Age groups, n } \\
\text { (col\%) }\end{array}$ & & & & & & $\begin{array}{l}< \\
0.0001^{\dagger}\end{array}$ \\
\hline & 40-59 years & $4(2.6)$ & $166(6.8)$ & $18(10.6)$ & $21(4.5)$ & $22(7.2)$ & \\
\hline & 60 to 79 years & $108(70.6)$ & $\begin{array}{l}1,389 \\
(56.6)\end{array}$ & $119(70.4)$ & $249(53.9)$ & $179(58.9)$ & \\
\hline & $\geq 80$ years & $41(26.8)$ & $897(36.6)$ & $32(18.9)$ & $192(41.6)$ & 103 (33.9) & \\
\hline & $\begin{array}{l}\text { Sex categories, } \mathrm{n} \\
\text { (col\%) }\end{array}$ & & & & & & $\begin{array}{l}<.0001^{\dagger} \\
<-1\end{array}$ \\
\hline & Male & $94(61.4)$ & $\begin{array}{l}1,429 \\
(58.3)\end{array}$ & $54(32.0)$ & $225(48.7)$ & $155(51.0)$ & \\
\hline & Female & $59(38.6)$ & $\begin{array}{l}1,023 \\
(41.7)\end{array}$ & $115(68.0)$ & $237(51.3)$ & $149(49.0)$ & \\
\hline & $\begin{array}{l}\text { Race categories, } \mathrm{n} \\
\text { (row\%) }\end{array}$ & & & & & & $0.268^{\dagger}$ \\
\hline & White & $96(62.7)$ & $\begin{array}{l}1,542 \\
(62.9)\end{array}$ & $111(65.7)$ & $277(60.0)$ & $198(65.1)$ & \\
\hline & Nonwhite & $31(20.3)$ & $450(18.3)$ & $27(16.0)$ & $100(21.6)$ & $41(13.5)$ & \\
\hline & Unknown/Missing & $26(17.0)$ & $460(18.8)$ & 31 (18.3) & 85 (18.4) & $65(21.4)$ & \\
\hline & Region, n (col \%) & & & & & & $0.194^{\dagger}$ \\
\hline & Midwest & $29(18.3)$ & $515(21.0)$ & 37 (21.9) & $102(22.1)$ & $70(23.0)$ & \\
\hline & Northeast & $12(7.8)$ & $287(11.7)$ & $22(13.0)$ & $63(13.6)$ & $31(10.2)$ & \\
\hline & South & $70(45.8)$ & $984(40.1)$ & $81(47.9)$ & $183(39.6)$ & $115(37.8)$ & \\
\hline & West & $42(27.4)$ & $657(26.8)$ & $29(17.2)$ & $114(24.7)$ & $88(28.9)$ & \\
\hline & Other & $1(0.6)$ & $9(0.4)$ & $0(0)$ & $0(0)$ & $0(0)$ & \\
\hline \multirow[t]{5}{*}{ Clinical } & $\begin{array}{l}\text { Combined } \\
\text { Charlson- } \\
\text { Elixhauser } \\
\text { comorbidity score, } \\
\text { mean (SD) }\end{array}$ & $1.6(1.9)$ & $1.9(2.4)$ & $1.9(2.1)$ & $2.2(2.5)$ & $2.2(2.4)$ & $0.0002^{\ddagger}$ \\
\hline & $\begin{array}{l}\text { Claims-based } \\
\text { frailty index, } \\
\text { mean (SD) }\end{array}$ & $0.20(0.05)$ & $\begin{array}{l}0.22 \\
(0.06)\end{array}$ & $0.22(0.06)$ & $0.23(0.07)$ & $0.23(0.07)$ & $<.0001^{\ddagger}$ \\
\hline & $\begin{array}{l}\text { CFI categories, } \mathrm{n} \\
(\mathrm{col} \%)\end{array}$ & & & & & & $\begin{array}{l}<.0001^{\dagger} \\
\end{array}$ \\
\hline & Robust & $24(15.7)$ & 301 (12.3) & $15(8.9)$ & $40(8.7)$ & $28(9.2)$ & \\
\hline & Prefrail & $104(68.0)$ & $\begin{array}{l}1,526 \\
(62.2)\end{array}$ & $100(59.2)$ & $253(54.8)$ & $173(56.9)$ & \\
\hline
\end{tabular}




\begin{tabular}{|c|c|c|c|c|c|c|c|}
\hline \multicolumn{2}{|c|}{ Characteristic Type } & \multirow{2}{*}{$\begin{array}{l}\text { Pimavanserin } \\
(\mathbf{n = 1 5 3 )} \\
20(13.1)\end{array}$} & \multirow{2}{*}{$\begin{array}{l}\text { Quetiapine } \\
(n=2,452)\end{array}$} & \multirow{2}{*}{$\begin{array}{l}\text { Aripiprazole } \\
(n=169) \\
48(28.4)\end{array}$} & \multirow{2}{*}{$\begin{array}{l}\text { Risperidone } \\
\begin{array}{l}(\mathbf{n}=\mathbf{4 6 2}) \\
149(32.3)\end{array}\end{array}$} & \multirow{2}{*}{$\begin{array}{l}\text { Olanzapine } \\
(\mathbf{n}=304) \\
84(27.6)\end{array}$} & \multirow[t]{2}{*}{ p-value } \\
\hline & Mildly frail & & & & & & \\
\hline & $\begin{array}{l}\text { Moderate to } \\
\text { severely frail }\end{array}$ & $5(3.3)$ & $111(4.5)$ & $6(3.5)$ & $20(4.3)$ & $19(6.2)$ & \\
\hline \multirow{4}{*}{$\begin{array}{l}\text { Healthcare } \\
\text { and } \\
\text { medication } \\
\text { use in } 6 \\
\text { months prior } \\
\text { to AP } \\
\text { initiation }\end{array}$} & $\begin{array}{l}\text { \# Medications } \\
\text { filled per month, } \\
\text { mean (SD) }\end{array}$ & $3.5(1.8)$ & $4.1(2.4)$ & $5.4(2.7)$ & $4.5(2.5)$ & $4.5(2.5)$ & $<.0001^{\ddagger}$ \\
\hline & $\begin{array}{l}\text { \# Neurology } \\
\text { visits, mean (SD) }\end{array}$ & $1.3(1.2)$ & $1.2(1.6)$ & $0.9(1.2)$ & $1.0(2.7)$ & $0.9(1.3)$ & $\begin{array}{l}<.0001^{\ddagger} \\
\end{array}$ \\
\hline & $\begin{array}{l}\text { \# ED visits, mean } \\
\text { (SD) }\end{array}$ & $0.3(0.7)$ & $0.5(1.4)$ & $0.8(2.5)$ & $0.6(1.2)$ & $0.7(2.2)$ & $0.0484^{\ddagger}$ \\
\hline & $\begin{array}{l}\text { \# Inpatient } \\
\text { admissions, mean } \\
\text { (SD) }\end{array}$ & $0.5(3.3)$ & $1.3(4.0)$ & $1.4(3.6)$ & $2.2(6.9)$ & $2.0(5.1)$ & $<.0001^{\ddagger}$ \\
\hline \multicolumn{8}{|c|}{$\begin{array}{l}\text { AP: antipsychotic; CFI: claims-based frailty index; ED: emergency department; IQR: interquartile range; SD: standard } \\
\text { deviation }\end{array}$} \\
\hline
\end{tabular}

The mean combined Charlson-Elixhauser comorbidity score differed significantly $(p=0.0002)$ across AP medications. However, the maximum difference of 0.6 points was well below the 2-3-point difference threshold associated with measurable variations in mortality and other health outcomes.[28, 29] Most study subjects met criteria for being "pre-frail" according to the CFI (54.8\% [risperidone] - 68.0\% [pimavanserin]). Quetiapine and pimavanserin users differed from initiators of the other APs by being more frequently categorized as "robust" (not frail) or "pre-frail" ( $<<0.0001)$; having fewer ED visits and hospitalizations, more outpatient neurology visits, and fewer medications in the six months prior to AP initiation ( $p$-values < 0.05).

\section{Discontinuation of overall antipsychotic therapy}

Overall, $38.6 \%$ of 3,566 individuals in our PD sample discontinued AP therapy after the first prescription; $61.4 \%$ continued with overal/ therapy within six months of initiation. As shown in Table 2, the six-month AP discontinuation rate varied by initial drug choice $(p<0001)$. Overall AP therapy discontinuation was lowest among pimavanserin initiators $(22.9 \%)$, and highest among individuals initially treated with risperidone (42.2\%). The median time to discontinuation of overall AP therapy was greatest among individuals started on pimavanserin at 168 days (IQR 71-213), followed by persons started on quetiapine (96.5 days, IQR 44-203), aripiprazole (85 days, IQR 44-190), and olanzapine (78 days, IQR 44-193.5). Risperidone therapy initiators had the shortest duration of therapy (72 days, IQR 44-186). 
Table 2

Treatment status after first antipsychotic prescription fill and time to discontinuation of overall antipsychotic therapy

\begin{tabular}{|c|c|c|c|c|c|c|}
\hline & $\begin{array}{l}\text { Pimavanserin } \\
(n=153)\end{array}$ & $\begin{array}{l}\text { Quetiapine } \\
(n=2,452)\end{array}$ & $\begin{array}{l}\text { Aripiprazole } \\
(n=169)\end{array}$ & $\begin{array}{l}\text { Risperidone } \\
(n=462)\end{array}$ & $\begin{array}{l}\text { Olanzapine } \\
(n=304)\end{array}$ & $p$-value \\
\hline \multicolumn{7}{|c|}{ Treatment status after first AP prescription fill } \\
\hline $\begin{array}{l}\text { Discontinued overall AP therapy, } \mathrm{n} \\
\text { (col\%) }\end{array}$ & $35(22.9)$ & $960(39.1)$ & $69(40.8)$ & $195(42.2)$ & $111(36.5)$ & $0.0006^{\dagger}$ \\
\hline $\begin{array}{l}\text { Persisted overall AP therapy, } \mathrm{n} \\
\text { (col\%) }\end{array}$ & $118(77.1)$ & $\begin{array}{l}1,492 \\
(60.8)\end{array}$ & $100(59.2)$ & $267(57.8)$ & $193(63.5)$ & \\
\hline Continued initial AP drug & $105(68.6)$ & $\begin{array}{l}1,369 \\
(55.8)\end{array}$ & $92(54.4)$ & $225(48.7)$ & $161(53.0)$ & $0.0005^{\dagger}$ \\
\hline $\begin{array}{l}\text { Switched to another AP } \\
\text { medication }\end{array}$ & $13(8.5)$ & $123(5.0)$ & $8(4.7)$ & $42(9.1)$ & $32(10.5)$ & $\begin{array}{l}< \\
0.0001^{\dagger}\end{array}$ \\
\hline $\begin{array}{l}\text { Median time to discontinuation of } \\
\text { overall AP therapy, days (IQR) }\end{array}$ & $\begin{array}{l}168(71- \\
213)\end{array}$ & $\begin{array}{l}96.5(44- \\
203)\end{array}$ & $\begin{array}{l}85(44- \\
190)\end{array}$ & $\begin{array}{l}72(44- \\
186)\end{array}$ & $\begin{array}{l}78(44- \\
193.5)\end{array}$ & $\begin{array}{l}< \\
0.0001^{\ddagger}\end{array}$ \\
\hline $\begin{array}{l}\text { Average supply of initial AP Rx, } \\
\text { days (SD) }\end{array}$ & $32.8(12.6)$ & $\begin{array}{l}35.8 \\
(19.8)\end{array}$ & $37.6(22.2)$ & $32.0(15.5)$ & $33.7(19.4)$ & $0.0007^{\ddagger}$ \\
\hline
\end{tabular}

Overall AP discontinuation was less likely in higher age groups as compared to those ages < 60: adjusted hazard ratios (AHRs) $0.83(95 \% \mathrm{Cl} 0.70-0.97)$ in the $60-79$ years group and $0.73(95 \% \mathrm{Cl} 0.62-0.87)$ in the $\geq 80$ years group, as well as in females (AHR $0.89,95 \% \mathrm{Cl} 0.89-0.97$ ) as compared to males. Increasing frequency of ED or outpatient neurology visits associated with a slightly higher risk of discontinuation (AHRs $1.04,95 \% \mathrm{Cl} 1.01-1.08$, and 1.03, 95\% $\mathrm{Cl} 1.01-1.05$, respectively). After adjusting for study covariates, the estimated AHRs for overall AP discontinuation were 1.76 (95\% Cl 1.40-2.20) for quetiapine, 2.15 $(95 \% \mathrm{Cl} 1.61-2.86)$ for aripiprazole, $2.12(95 \% \mathrm{Cl} 1.66-2.72)$ for risperidone, $2.07(95 \% \mathrm{Cl} 1.60-2.67)$ for olanzapine as compared to pimavanserin, as shown in Fig. 1. The Kaplan-Meier curve for the length of time after initiation of APs of interest until discontinuation of overall AP therapy also showed a statistically significant difference in the freedom from discontinuation times between the five groups $(p<0.0001)$ as shown in eFigure 1.

\section{Persistence to initial antipsychotic therapy}

Switching from one AP to another was much less common than stopping treatment altogether; almost $6.0 \%$ of subjects switched. AP drug changes occurred most frequently among initiators of olanzapine (10.5\%), and least frequently among those taking quetiapine first (4.9\%). As shown in Table 3, persons prescribed pimavanserin, aripiprazole, risperidone, and olanzapine, who switched to another AP, overwhelmingly switched to quetiapine (91.7\%, 75.0\%, 66.7\%, and $62.5 \%$, respectively). PD patients initially prescribed quetiapine who switched were most often given risperidone (28.3\%), pimavanserin (26.7\%), or olanzapine (20.0\%). 
Table 3

Switching proportion and patterns from initial therapy within 6 months, stratified by initial antipsychotic prescribed

\begin{tabular}{|c|c|c|c|c|c|c|c|}
\hline \multirow[t]{2}{*}{ Initial Agent } & \multirow{2}{*}{$\begin{array}{l}\text { Switched, } \\
\text { n (row\%) }\end{array}$} & \multicolumn{6}{|c|}{ Switching to drug, n (row \%) } \\
\hline & & $\mathbf{P}$ & Q & A & $\mathbf{R}$ & 0 & Other antipsychotic \\
\hline $\begin{array}{l}\text { Pimavanserin } \\
(n=153)\end{array}$ & $12(7.8)$ & - & $11(91.7)$ & $0(0)$ & $0(0)$ & $0(0)$ & $1(8.3)$ \\
\hline $\begin{array}{l}\text { Quetiapine } \\
(n=2,452)\end{array}$ & $120(4.9)$ & $32(26.7)$ & - & $6(5.0)$ & $34(28.3)$ & $24(20.0)$ & $24(20.0)$ \\
\hline $\begin{array}{l}\text { Aripiprazole } \\
(n=169)\end{array}$ & $8(4.7)$ & $0(0)$ & $6(75.0)$ & - & $1(12.5)$ & $1(12.5)$ & $0(0)$ \\
\hline $\begin{array}{l}\text { Risperidone } \\
(n=462)\end{array}$ & $39(8.4)$ & $0(0)$ & $26(66.7)$ & $2(5.1)$ & - & 7 (17.9) & $4(10.3)$ \\
\hline $\begin{array}{l}\text { Olanzapine } \\
(n=304)\end{array}$ & $32(10.5)$ & $2(6.2)$ & $20(62.5)$ & $1(3.1)$ & $6(18.7)$ & - & $3(9.4)$ \\
\hline
\end{tabular}

Discontinuation of initial AP inversely associated with age $\geq 80$ (AHR $0.75,95 \% \mathrm{Cl} 0.63-0.89$ ), but did not associate race, sex, $\mathrm{CFI}$, combined Charlson-Elixhauser comorbidity score, or incremental increases in recent average health care use. Both unadjusted and adjusted Cox proportional hazards models for the six-month follow-up and an allowable gap of 14 days between fills found a higher risk of discontinuation among PD patients initiated on quetiapine (hazard ratio [HR] $1.44,95 \% \mathrm{Cl}$ 1.17-1.79; AHR 1.57, 95\% Cl 1.28-1.94), aripiprazole (HR 1.61, 95\% Cl 1.23-2.12; AHR 1.88, 95\% Cl 1.43-2.46), risperidone (HR $1.87,95 \% \mathrm{Cl} 1.48-2.36$; AHR 2.00, 95\% Cl 1.59-2.52), and olanzapine (HR 1.86, 95\% Cl 1.45-2.37; AHR 2.03, 95\% Cl 1.60-2.58) as compared to pimavanserin (Fig. 2). The Kaplan-Meier curve for the length of time after initiation of APs of interest until discontinuation of that specific AP also showed a statistically significant difference in the freedom from discontinuation times between five treatment options $(p<0.0001)$ as shown in eFigure 2 .

Sensitivity analyses that expanded the observation window for discontinuation from 6 to 12 months and the allowable refill gap from 14 to 30 days yielded similar findings as our primary analyses (eTables 2-7). Individuals who had no ED visits or hospitalizations in the six months prior to AP therapy initiation also had similar discontinuation rates.

\section{Discussion}

Psychotic symptoms in PD are relatively common and consistently associated with negative health outcomes such as caregiver stress,[34] nursing home placement,[2, 35] and mortality.[35] Using real-world data, we examined the use of AP drugs most commonly prescribed to PD patients in the United States. Our primary findings are (1) AP therapy is discontinued often and (2) AP therapy discontinuation and switching are greater among users of APs with complex receptor blocking properties, including greater dopamine-receptor blocking activity (i.e., quetiapine, aripiprazole, risperidone, and olanzapine), as compared to serotonin receptor-specific pimavanserin.

Our finding that almost $40 \%$ of individuals with PD stop overall AP treatment after the first prescription has multiple potential explanations. One potential explanation is an improvement in the symptoms for which the AP was prescribed. The first step in the detection and diagnosis of psychosis is to identify treatable or transient triggers. Infection, illness, sleep disruption, depression can lead to reversible psychosis in older adults.[36-38] Certainly, some of the PD patients in our sample could have 
had a psychosis cause identified and successfully addressed, with no need for long-term AP therapy. However, our sensitivity analyses suggested few patients in our sample had recent inpatient or emergent care that would reasonably be expected to associate with clinical indications for temporary AP therapy. In contrast, psychosis due to PD-related processes usually does not respond to attempts to wean the AP.[39]

Adverse drug reactions may also have played a role in the AP use patterns we observed. APs with the highest dopaminereceptor blocking potential (i.e., aripiprazole, risperidone, and olanzapine) had the lowest persistence to therapy and highest switching rate as compared to pimavanserin and quetiapine; this finding could reflect drug intolerance or adverse effects.[13, $14,40]$ Double-blind trials of olanzapine demonstrated no psychosis improvement and consistent worsening of motor function, even at low doses.[5, 41] A meta-analysis of risperidone treatment reported that one-third of PD patients experienced increased motor dysfunction.[35, 42-44] Aripiprazole is thought to carry a lower risk of extrapyramidal adverse effects due to its high relative affinity for serotonergic receptors as compared to dopamine receptors; $[13,14]$ however, emergent motor dysfunction in a single-arm open-label study of aripiprazole for PDP led to the study termination. $[4,42,45,46]$ Others who discontinued AP therapy may have done so because of a lack of response, partial response, or failure to meet patient/caregiver response expectations.

AP therapy use for behavioral symptoms and insomnia is strongly discouraged in geriatric clinical guidelines because it is likely to be ineffective and cause adverse effects.[9, 11, 47-50] Nevertheless, aborted trials of AP drugs for behavioral symptoms, such as agitation, pacing, yelling, sleep dysfunction, nocturnal restlessness, or insomnia, also likely account for a portion of the observed discontinuations. These symptoms are common in PD, especially in later disease stages, and cause significant caregiver distress.[8, 51, 52] Pimavanserin may be less likely to be used for behavioral management, as U.S. prescribers must provide medical documentation of psychosis as the reason for use.[53] If similar clinical documentation was required for all AP prescribing, the unmet need for management of behavioral and sleep disorders would become more evident, as would potentially inappropriate AP use. Future prospective studies will examine the frequency with which AP therapy is being used (in part or whole) for PD-related behavioral disturbances and measure clinical and safety outcomes associated with these off-label, potentially contraindicated uses.

\section{Study strengths}

Our study had several strengths. Using a large healthcare database of commercially insured individuals in the U.S.[22] enabled us to examine AP prescribing in a diverse PD population sample, including older adults, women, and minorities, groups that are usually excluded from clinical trials. Prescription fills are well-captured in claims data and are preferred over self-reported medication use for adherence and persistence studies; the latter are subject to reporting and desirability bias.[54] Our methods for eligibility, exposure, and outcome measures are standard for pharmacoepidemiologic studies of treatment adherence and persistence.[24, 31-33] Finally, our study provides comparative real-world data on all used medications, including the recently approved pimavanserin; such multi-drug comparisons are only possible using real-world observational data.

\section{Study limitations}

Despite these strengths, our study also has limitations. Optum contains commercially insured individuals, which often associates with younger age, fewer or less severe comorbid conditions, and higher average income. Newer, more expensive, or more interaction-prone AP drug choices may therefore be over-represented in our sample. Optum does not contain research instruments or clinical documentation (i.e., psychiatric evaluation results) of AP treatment response or the symptom profile. To address this limitation, it might be reasonable to consider large electronic health record (EHR) databases, although retrospective analyses of EHR data will still be subject to reporting bias.[55] Psychosis may improve with cholinesterase inhibitors (e.g., donepezil, rivastigmine, galantamine),[4] metacognitive therapy, or electroconvulsive therapy,[56] but examining the use of these other treatment was beyond the scope of the current study. Finally, there was a potential for exposure misclassification due to the limited grace period allowed between prescription fills of APs.

\section{Conclusions}


Our study highlights that persistence to AP therapy is generally low in PD patients. Future studies are needed to parse the contributing effects of treatment intolerance or ineffectiveness, prescribing appropriateness, patient non-adherence, and symptom resolution on psychosis treatment patterns, thus opening better symptom control opportunities.

\section{Abbreviations}

5-HT2A: serotonin type 2A

AHR: adjusted hazard ratio

AP: antipsychotic

CFI: claims-based frailty index

Cl: confidence interval

D2: dopamine type 2

ED: emergency department

EHR: electronic health record

HR: hazard ratio

ICD-9-CM: International Classification of Diseases, $9^{\text {th }}$ Revisions, Clinical Modification

ICD-10-CM: International Classification of Diseases, $10^{\text {th }}$ Revisions, Clinical Modification

IQR: interquartile range

PD: Parkinson disease

PDP: Parkinson disease psychosis

U.S.: United States

\section{Declarations}

\section{Ethics approval and consent to participate:}

The Office of Regulatory Affairs of the University of Pennsylvania (Philadelphia, PA) granted Institutional Review Board exemption for all research studies performed using the Optumlnsight medical claims database through the university (University of Pennsylvania's protocol \#819924) and waived the need for consent to participate due to the de-identified nature of Optum data.

\section{Consent for publication:}

Not applicable

\section{Availability of data and materials:}

De-identified Optum data used in this study are available to any interested researchers for purchase.

\section{Competing interests:}


Dr. Pham Nguyen receives support from the National Institute of Health [Grant \#R01 NS099129]. Dr. Abraham receives support from the National Institute of Health [Grant \#R01 NS099129] and the Parkinson's Foundation. Dr. Weintraub receives support from the National Institutes of Health [Grant \#R01 NS099129] and has also received research funding or support from Michael J. Fox Foundation for Parkinson's Research, Alzheimer's Therapeutic Research Initiative (ATRI), Alzheimer's Disease Cooperative Study (ADCS), the International Parkinson and Movement Disorder Society (IPMDS); honoraria for consultancy from Acadia, Aptinyx, Biogen, Bracket, CHDI Foundation, Clintrex LLC, Enterin, F. Hoffmann-La Roche Ltd, Ferring, Promentis, Sunovion, and Takeda; and license fee payments from the University of Pennsylvania for the QUIP and QUIP-RS. Dr. Willis receives financial support from National Institutes of Health [Grant \#R01 NS099129], the Parkinson's Foundation, and the University of Pennsylvania. Mr. Thibault declared no competing interests for this work.

\section{Funding:}

None

\section{Authors' contributions:}

TPPN had full access to all the data used in the study and takes responsibility for the integrity of the data and the accuracy of the data analysis.

Concept and design: TPPN, DSA, AWW

Acquisition, analysis, or interpretation of data: TPPN, DSA, AWW

Drafting of the manuscript: TPPN, AWW

Critical revision of the manuscript for important intellectual content: TPPN, DSA, DT, DW, AWW

Statistical analysis: TPPN, DT

Administrative, technical, or material support: DSA, DT, DW, AWW

\section{Acknowledgements:}

Not applicable

\section{References}

1. Weintraub D, Mamikonyan E. The Neuropsychiatry of Parkinson Disease: A Perfect Storm. Am J Geriatr Psychiatry. 2019;27 9:998-1018; doi: 10.1016/j.jagp.2019.03.002.

2. Fenelon G, Alves G. Epidemiology of psychosis in Parkinson's disease. J Neurol Sci. 2010;289 1-2:12-7; doi: 10.1016/j.jns.2009.08.014.

3. Taddei RN, Cankaya S, Dhaliwal S, Chaudhuri KR. Management of Psychosis in Parkinson's Disease: Emphasizing Clinical Subtypes and Pathophysiological Mechanisms of the Condition. Parkinsons Dis. 2017;2017:3256542; doi: $10.1155 / 2017 / 3256542$.

4. Chen JJ. Treatment of psychotic symptoms in patients with Parkinson disease. Ment Health Clin. 2017;7 6:262-70; doi: 10.9740/mhc.2017.11.262.

5. Seppi K, Ray Chaudhuri K, Coelho M, Fox SH, Katzenschlager R, Perez Lloret S, et al. Update on treatments for nonmotor symptoms of Parkinson's disease-an evidence-based medicine review. Mov Disord. 2019;34 2:180-98; doi: $10.1002 /$ mds. 27602.

6. Rigby HB, Rehan S, Hill-Taylor B, Matheson K, Sketris I. Antipsychotic Prescribing Practices in Those with Parkinsonism: Adherence to Guidelines. Can J Neurol Sci. 2017;44 5:603-6; doi: 10.1017/cjn.2017.36. 
7. Herrmann N, Marras C, Fischer HD, Wang X, Anderson GM, Rochon PA. Management of neuropsychiatric symptoms in long-term care residents with Parkinson's disease: a retrospective cohort study. Drugs Aging. 2013;30 1:19-22; doi:

$10.1007 /$ s40266-012-0038-8.

8. Goldman JG. Neuropsychiatric Issues in Parkinson Disease. Continuum (Minneap Minn). 2016;22 4 Movement Disorders:1086-103; doi: 10.1212/CON.0000000000000353.

9. Ford AH, Almeida OP. Management of Depression in Patients with Dementia: Is Pharmacological Treatment Justified? Drugs Aging. 2017;34 2:89-95; doi: 10.1007/s40266-016-0434-6.

10. Tampi RR, Tampi DJ, Balachandran S, Srinivasan S. Antipsychotic use in dementia: a systematic review of benefits and risks from meta-analyses. Ther Adv Chronic Dis. 2016;7 5:229-45; doi: 10.1177/2040622316658463.

11. American Geriatrics Society 2019 Updated AGS Beers Criteria ${ }^{\circledR}$ for Potentially Inappropriate Medication Use in Older Adults. J Am Geriatr Soc. 2019;67 4:674-94; doi: 10.1111/jgs.15767.

12. Crocco EA, Jaramillo S, Cruz-Ortiz C, Camfield K. Pharmacological Management of Anxiety Disorders in the Elderly. Curr Treat Options Psychiatry. 2017;4 1:33-46; doi: 10.1007/s40501-017-0102-4.

13. Gareri P, Segura-Garcia C, Manfredi VG, Bruni A, Ciambrone P, Cerminara G, et al. Use of atypical antipsychotics in the elderly: a clinical review. Clin Interv Aging. 2014;9:1363-73; doi: 10.2147/CIA.S63942.

14. Aringhieri S, Carli M, Kolachalam S, Verdesca V, Cini E, Rossi M, et al. Molecular targets of atypical antipsychotics: From mechanism of action to clinical differences. Pharmacol Ther. 2018;192:20-41; doi: 10.1016/j.pharmthera.2018.06.012.

15. Lako IM, van den Heuvel ER, Knegtering H, Bruggeman R, Taxis K. Estimating dopamine D(2) receptor occupancy for doses of 8 antipsychotics: a meta-analysis. J Clin Psychopharmacol. 2013;33 5:675-81; doi: 10.1097/JCP.0b013e3182983ffa.

16. Cummings J, Isaacson S, Mills R, Williams H, Chi-Burris K, Corbett A, et al. Pimavanserin for patients with Parkinson's disease psychosis: a randomised, placebo-controlled phase 3 trial. Lancet. 2014;383 9916:533-40; doi: 10.1016/S01406736(13)62106-6.

17. Ndukwe HC, Nishtala PS. Time-to-First Discontinuation, Adherence and Persistence in New Users of Second-Generation Antipsychotics. J Clin Psychopharmacol. 2016;36 6:649-57; doi: 10.1097/JCP.0000000000000597.

18. Stuijt C, Karapinar-Carkit F, van den Bemt B, van Laar T. Effect of Pharmacist-Led Interventions on (Non)Motor Symptoms, Medication-Related Problems, and Quality of Life in Parkinson Disease Patients: A Pilot Study. Clin Neuropharmacol. 2018;41 1:14-9; doi: 10.1097/WNF.0000000000000260.

19. Daley DJ, Deane KH, Gray RJ, Clark AB, Pfeil M, Sabanathan K, et al. Adherence therapy improves medication adherence and quality of life in people with Parkinson's disease: a randomised controlled trial. Int J Clin Pract. 2014;68 8:963-71; doi: 10.1111/ijcp.12439.

20. Azermai M, Vander Stichele RR, Van Bortel LM, Elseviers MM. Barriers to antipsychotic discontinuation in nursing homes: an exploratory study. Aging Ment Health. 2014;18 3:346-53; doi: 10.1080/13607863.2013.832732.

21. Devanand DP, Mintzer J, Schultz S, Sultzer D, de la Pena D, Gupta S, et al. The antipsychotic discontinuation in Alzheimer disease trial: clinical rationale and study design. Am J Geriatr Psychiatry. 2012;20 4:362-73; doi:

10.1097/JGP.0b013e3182110563.

22. OptumTM. Real world health care experiences from over 150 million unique individuals since 1993. https://www.optum.com/content/dam/optum/resources/productSheets/5302_Data_Assets_Chart_Sheet_ISPOR.pdf (2015, June). Accessed.

23. Barnett JC BE: Health Insurance Coverage in the United States: 2016. In: Current Population Reports. Washington, DC: United States Census Bureau; 2017: 60-260.

24. Leonard CE, Brensinger CM, Pham Nguyen TP, Horn JR, Chung S, Bilker WB, et al. Screening to identify signals of opioid drug interactions leading to unintentional traumatic injury. Biomed Pharmacother. 2020;130:110531; doi:

10.1016/j.biopha.2020.110531.

25. Lund JL, Richardson DB, Sturmer T. The active comparator, new user study design in pharmacoepidemiology: historical foundations and contemporary application. Curr Epidemiol Rep. 2015;2 4:221-8; doi: 10.1007/s40471-015-0053-5.

Page $12 / 15$ 
26. Wermuth L, Lassen CF, Himmerslev L, Olsen J, Ritz B. Validation of hospital register-based diagnosis of Parkinson's disease. Dan Med J. 2012;59 3:A4391.

27. Swarztrauber K, Anau J, Peters D. Identifying and distinguishing cases of parkinsonism and Parkinson's disease using ICD9 CM codes and pharmacy data. Mov Disord. 2005;20 8:964-70; doi: 10.1002/mds.20479.

28. Gagne JJ, Glynn RJ, Avorn J, Levin R, Schneeweiss S. A combined comorbidity score predicted mortality in elderly patients better than existing scores. J Clin Epidemiol. 2011;64 7:749-59; doi: 10.1016/j.jclinepi.2010.10.004.

29. Sun JW, Rogers JR, Her Q, Welch EC, Panozzo CA, Toh S, et al. Adaptation and Validation of the Combined Comorbidity Score for ICD-10-CM. Med Care. 2017;55 12:1046-51; doi: 10.1097/MLR.0000000000000824.

30. Kim DH, Schneeweiss S, Glynn RJ, Lipsitz LA, Rockwood K, Avorn J. Measuring Frailty in Medicare Data: Development and Validation of a Claims-Based Frailty Index. J Gerontol A Biol Sci Med Sci. 2018;73 7:980-7; doi: 10.1093/gerona/glx229.

31. Desai PR, Adeyemi AO, Richards KM, Lawson KA. Adherence to oral diabetes medications among users and nonusers of antipsychotic medication. Psychiatr Serv. 2014;65 2:215-20; doi: 10.1176/appi.ps.201300118.

32. Roux B, Sirois C, Simard M, Gagnon ME, Laroche ML. One-year persistence of potentially inappropriate medication use in older adults: A population-based study. Br J Clin Pharmacol. 2020;86 6:1062-80; doi: 10.1111/bcp.14214.

33. Pham Nguyen TP, Chen Y, Thibault D, Leonard CE, Hennessy S, Willis A. Impact of Hospitalization and Medication Switching on Post-discharge Adherence to Oral Anticoagulants in Patients With Atrial Fibrillation. Pharmacotherapy. 2020;40 10:1022-35; doi: 10.1002/phar.2457.

34. Zahodne LB, Fernandez HH. Pathophysiology and treatment of psychosis in Parkinson's disease: a review. Drugs Aging. 2008;25 8:665-82; doi: 10.2165/00002512-200825080-00004.

35. Fernandez HH, Trieschmann ME, Friedman JH. Treatment of psychosis in Parkinson's disease: safety considerations. Drug Saf. 2003;26 9:643-59; doi: 10.2165/00002018-200326090-00004.

36. Broadway J, Mintzer J. The many faces of psychosis in the elderly. Curr Opin Psychiatry. 2007;20 6:551-8; doi: 10.1097/YCO.0b013e3282f0f09d.

37. Reinhardt MM, Cohen Cl. Late-life psychosis: diagnosis and treatment. Curr Psychiatry Rep. 2015;17 2:1; doi: 10.1007/s11920-014-0542-0.

38. Lindgren M, Torniainen-Holm M, Harkanen T, Dickerson F, Yolken RH, Suvisaari J. The association between toxoplasma and the psychosis continuum in a general population setting. Schizophr Res. 2018;193:329-35; doi:

10.1016/j.schres.2017.06.052.

39. Fernandez HH, Trieschmann ME, Okun MS. Rebound psychosis: effect of discontinuation of antipsychotics in Parkinson's disease. Mov Disord. 2005;20 1:104-5; doi: 10.1002/mds.20260.

40. Roussidis A, Kalkavoura C, Dimelis D, Theodorou A, loannidou I, Mellos E, et al. Reasons and clinical outcomes of antipsychotic treatment switch in outpatients with schizophrenia in real-life clinical settings: the ETOS observational study. Ann Gen Psychiatry. 2013;12 1:42; doi: 10.1186/1744-859X-12-42.

41. Breier A, Sutton VK, Feldman PD, Kadam DL, Ferchland I, Wright P, et al. Olanzapine in the treatment of dopamimeticinduced psychosis in patients with Parkinson's disease. Biol Psychiatry. 2002;52 5:438-45; doi: 10.1016/s00063223(02)01392-6.

42. Iketani R, Kawasaki Y, Yamada H. Comparative Utility of Atypical Antipsychotics for the Treatment of Psychosis in Parkinson's Disease: A Systematic Review and Bayesian Network Meta-analysis. Biol Pharm Bull. 2017;40 11:1976-82; doi: 10.1248/bpb.b17-00602.

43. Wilby KJ, Johnson EG, Johnson HE, Ensom MHH. Evidence-Based Review of Pharmacotherapy Used for Parkinson's Disease Psychosis. Ann Pharmacother. 2017;51 8:682-95; doi: 10.1177/1060028017703992.

44. Factor SA, Molho ES, Friedman JH. Risperidone and Parkinson's disease. Mov Disord. 2002;17 1:221-2; doi: 10.1002/mds.1258.

45. Friedman JH, Berman RM, Goetz CG, Factor SA, Ondo WG, Wojcieszek J, et al. Open-label flexible-dose pilot study to evaluate the safety and tolerability of aripiprazole in patients with psychosis associated with Parkinson's disease. Mov 
Disord. 2006;21 12:2078-81; doi: 10.1002/mds.21091.

46. Kohen I, Lester PE, Lam S. Antipsychotic treatments for the elderly: efficacy and safety of aripiprazole. Neuropsychiatr Dis Treat. 2010;6:47-58; doi: 10.2147/ndt.s6411.

47. Doody RS, Stevens JC, Beck C, Dubinsky RM, Kaye JA, Gwyther L, et al. Practice parameter: management of dementia (an evidence-based review). Report of the Quality Standards Subcommittee of the American Academy of Neurology.

Neurology. 2001;56 9:1154-66; doi: 10.1212/wnl.56.9.1154.

48. Carson S, McDonagh MS, Peterson K. A systematic review of the efficacy and safety of atypical antipsychotics in patients with psychological and behavioral symptoms of dementia. J Am Geriatr Soc. 2006;54 2:354-61; doi: 10.1111/j.1532-

5415.2005.00566.x.

49. Hersch EC, Falzgraf S. Management of the behavioral and psychological symptoms of dementia. Clin Interv Aging. 2007;2 4:611-21; doi: 10.2147/cia.s1698.

50. Bessey LJ, Walaszek A. Management of Behavioral and Psychological Symptoms of Dementia. Curr Psychiatry Rep. 2019;21 8:66; doi: 10.1007/s11920-019-1049-5.

51. Amara AW, Chahine LM, Videnovic A. Treatment of Sleep Dysfunction in Parkinson's Disease. Curr Treat Options Neurol. 2017;19 7:26; doi: 10.1007/s11940-017-0461-6.

52. Bonnet AM, Jutras MF, Czernecki V, Corvol JC, Vidailhet M. Nonmotor symptoms in Parkinson's disease in 2012: relevant clinical aspects. Parkinsons Dis. 2012;2012:198316; doi: 10.1155/2012/198316.

53. Livezey S, McCormick R, Shah NB, Choi L, DeClercq J, Zuckerman AD. Impact of specialty pharmacist integration on time to medication access for pimavanserin. J Drug Assess. 2019;8 Suppl 1:29.

54. Andrade SE, Kahler KH, Frech F, Chan KA. Methods for evaluation of medication adherence and persistence using automated databases. Pharmacoepidemiol Drug Saf. 2006;15 8:565-74; discussion 75-7; doi: 10.1002/pds.1230.

55. Lee S, Xu Y, AG DAS, Martin EA, Doktorchik C, Zhang Z, et al. Unlocking the Potential of Electronic Health Records for Health Research. Int J Popul Data Sci. 2020;5 1:1123; doi: 10.23889/ijpds.v5i1.1123.

56. Black KJ, Nasrallah H, Isaacson S, Stacy M, Pahwa R, Adler CH, et al. Guidance for switching from off-label antipsychotics to pimavanserin for Parkinson's disease psychosis: an expert consensus. CNS Spectr. 2018;23 6:402-13; doi: $10.1017 /$ S1092852918001359.

\section{Figures}

\begin{tabular}{|c|c|c|}
\hline Effect & Adjusted HR & $95 \% \mathrm{Cl}$ \\
\hline \multicolumn{3}{|l|}{ Antipsychotics } \\
\hline Quetiapine vs Pimavanserin & 1.76 & $1.40-2.20$ \\
\hline Aripiprazole vs Pimavanserin & 2.15 & $1.61-2.86$ \\
\hline Risperidone vs Pimavanserin & 2.12 & $1.66-2.72$ \\
\hline Olanzapine vs Pimavanserin & 2.07 & $1.60-2.67$ \\
\hline \multicolumn{3}{|l|}{ Clinical } \\
\hline Claims-based frailty index & 1.44 & $0.66-3.13$ \\
\hline Combined Charlson-Elixhauser comorbidity score & 1.00 & $0.98-1.02$ \\
\hline \multicolumn{3}{|l|}{ Health care utilization } \\
\hline Average medication filled per month in prior 6 months & 0.95 & 0.93-0.97 \\
\hline Average inpatient admission in prior 6 months & 1.01 & $1.00-1.02$ \\
\hline Average emergency department visit in prior 6 months & 1.04 & $1.01-1.08$ \\
\hline Average neurology visit in prior 6 months & 1.03 & $1.01-1.05$ \\
\hline Days supply of initial antipsychotic prescription & 0.99 & $0.98-0.99$ \\
\hline \multicolumn{3}{|l|}{ Demographic } \\
\hline $60-79$ years old vs $40-59$ years old & 0.83 & $0.70-0.97$ \\
\hline$\geq 80$ years old vs $40-59$ years old & 0.73 & $0.62-0.87$ \\
\hline Female vs Male & 0.89 & $0.89-0.97$ \\
\hline Non-white vs White & 1.11 & $1.00-1.24$ \\
\hline Unknown/Missing race vs White & 0.93 & $0.84-1.04$ \\
\hline Region Midwest vs West & 0.88 & $0.78-1.00$ \\
\hline Region Northeast vs West & 0.87 & $0.75-1.01$ \\
\hline Region Other vs West & 1.53 & $0.67-3.51$ \\
\hline Region South vs West & 0.92 & $0.83-1.02$ \\
\hline
\end{tabular}

\section{Figure 1}


Factors associated with risk of overall antipsychotic discontinuation within six months among Parkinson disease patients Cl: confidence interval; HR: hazard ratio

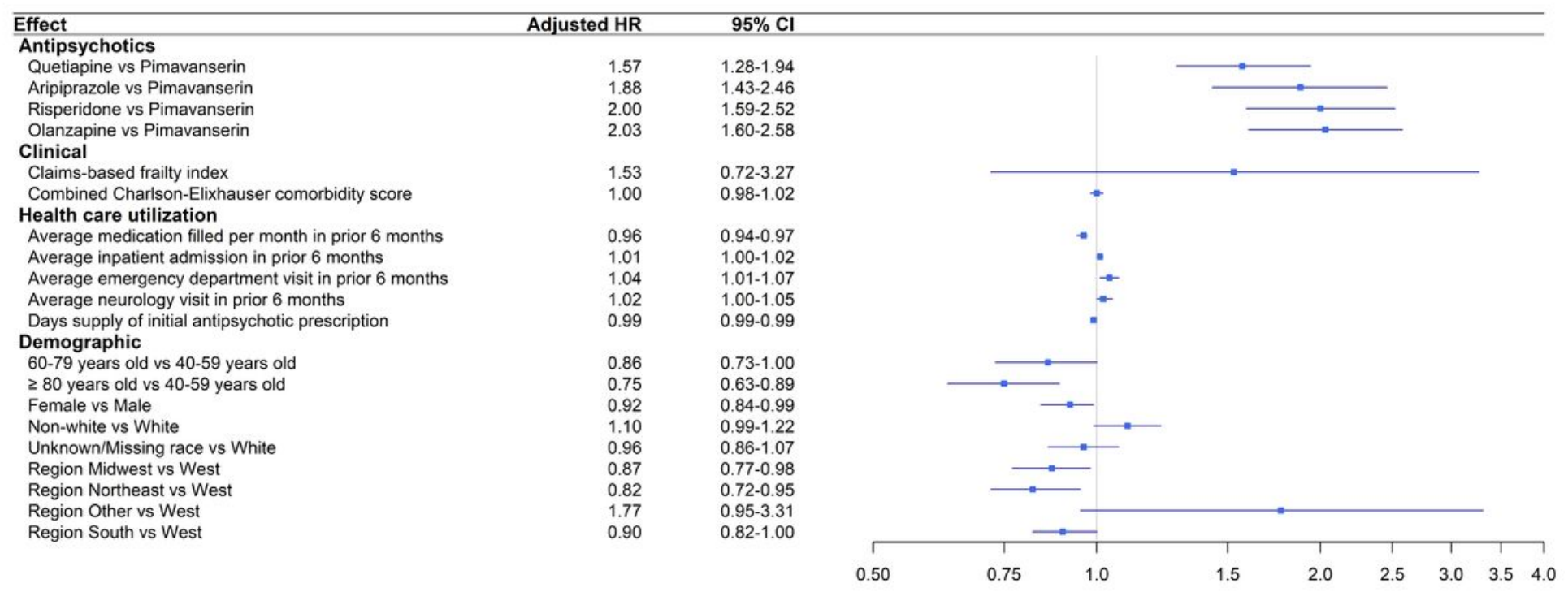

\section{Figure 2}

Factors associated with risk of initial antipsychotic discontinuation within six months among Parkinson disease patients Cl: confidence interval; HR: hazard ratio

\section{Supplementary Files}

This is a list of supplementary files associated with this preprint. Click to download.

- SUPPLFIGURESAPDISCONTINUATIONTPPNBMCNeuro.docx

- SUPPLTABLESAPDISCONTINUATIONTPPNBMCNeuro.docx 